view wider horizons, with his visits to Overseas Branches and his contact with Commonwealth and international affiliations; and Dr. S. J. HAdFIELD, secretary to the Central Ethical Committee, who gave an account of its work.

Dr. F. E. Gould (Birmingham) asked why the head office had waited so long before asking Divisions to put into operation the revised ethical rules which were passed at the last Annual Representative Meeting, and whether a special general meeting of Divisions was necessary. The SeCreTary replied that the rules were approved at the adjourned A.R.M. in September. The delay had been largely caused by printing difficulties. The rules formed a very long and detailed document which had to be examined very carefully, and it was only during the last ten days or so that the final print could be sent out. There was no need for a special general meeting to be called for the adoption of the rules; they could be adopted at any general meeting. The Representative Body had said that it would not take responsibility for any ethical proceedings after July 31 of this year except under the revised rules, but in view of the delay in getting them out to Divisions he thought a point could be stretched. It was in only three or four Divisions each year that a case arose in which an inquiry had to be undertaken.

\section{Recruitment of Doctors}

The North of England Branch brought forward the question of the recruitment of doctors in the event of a national emergency. It was felt in this area that the work done by the old Local Medical War Committees was beyond reproach, and that these should not be supplanted by untried organization.

The question of the introduction of a lay element into the local medical war committee brought forward diverse opinions, but the Conference was averse from taking any vote on the subject. One speaker wanted an assurance that the new scheme would impose more or less equality of sacrifice as between practitioners in different areas and as between general practitioners and other members of the profession.

\section{THE PRESIDENT'S ADDRESS}

It is hoped that many members of the Association, apart from those attending the Annual Representative Meeting, will honour the new President, Dr. A. W. S. Sichel, of Capetown, by their presence at the Adjourned Annual General Meeting on Wednesday, June 15, when Dr. Sichel will deliver the President's Address.

The meeting will be held in the Central Hall, Westminster, at 8 p.m., and will be followed at 9.15 p.m. by the President's Reception in the same building. Both functions are open to members of the Association and their ladies, so far as space permits. Admission will be by ticket, and members wishing to be present should apply to the Secretary of the Association at B.M.A. House, stating the number of tickets desired $(a)$ for the President's Address and $(b)$ for the President's Reception. Evening dress with decorations and academic robes will be worn.

\section{ASSOCIATION DANCE}

A dance open to all members of the Association and their ladies will be held at 9.30 p.m. on Wednesday, June 13, at the Dorchester Hotel after the Representatives' Dinner. Light refreshments will be served, and dancing will continue until 12.30 a.m. Members are invited to apply for tickets (10s. each) as soon as possible to the Secretary, B.M.A. House, Tavistock Square, London, W.C.1.

Correction.-Minimum Salary for Assistants: In paragraph 206 of the Supplementary Annual Report of Council (Supplement, May 12, p. 183) the word "(indoor)" should be deleted.

\section{Correspondence}

\section{Barred from Medical Lists}

SIR, - I am genuinely alarmed and worried by the findings of the Tribunal as reported in the Supplement of May 19 (p. 206) and I do hope that at least some discussion will take place on the point I wish to raise. The Tribunal had unanimously decided that there was no negligence on the part of the doctor and that the deceased did not die as a result of any negligence or lack of professional skill on the part of the respondent. There was no failure on the doctor's part to give such treatment as might have saved Mrs. Smith's life. The doctor's failure to visit her did not cause or contribute to her death. Yet, Sir, after considering all the facts of the case the Tribunal was unanimously of the opinion that the doctor ought to have visited Mrs. Smith when asked to do so by her husband and that he had no reasonable excuse for not doing so.

While the harsh (and novel) sentence may or may not have been properly deserved-there were three previous cases against the doctor taken into account-I fail to see how anybody could reconcile the sentence with the first part of the Tribunal's findings, and how the Minister could dismiss the appeal in the face of such a glaring incongruity of the two parts. It would be interesting to know what would have been the Tribunal's verdict if Mrs. Smith had not died.

If the first part was true (?), then in future which doctor will ever be safe to refuse a visit, however frivolous, trivial, and unnecessary, for fear of being barred from practising medicine under the National Health Service from Land's End to John o' Groat's? There are other extraordinary and inexplicable features in this case that call for clarification and that make one regret that the doctors did not get the "reference to courts" granted by the Act. May we hope, Sir, that some editorial expression of opinion will be forthcoming on this most disquieting position that has now been created ?-I am, etc.,

$$
\text { London, W:10. }
$$

George de Swiet.

\section{The Prices Spiral}

SIR,-As the prices of commodities essential to general practice (petrol, cars, and soon telephones and postage, etc.) continue to rise in a sharp spiral, the G.P. himself is slowly being crushed out of orthodox practice. Unlike any other trade or profession he is unable to meet these new price increases by increasing his fees, which are of course in the main fixed by the Government. The G.P., therefore, if he wishes to keep out of ever-increasing debt must effect economies which greatly lower his standard of practice.

Owing to the increased cost of transport and its maintenance patients who live at any great distance will be visited at the barest minimum or asked to transfer to a more local man, which of course nullifies the free choice of doctor. The great increase in the clerical costs of practice-i.e., telephones, postage, and printing-will, when their effects are fully felt, necessitate essential economy in any secretarial assistance, and so a decline of a very important adjunct to general practice will ensue (adequate and efficient records, etc.). The maintaining of an adequate standard of comfort in surgeries and waiting-rooms is almost precluded by the increased costs of repairs and renewals to furniture and interior decorating, and heating must of necessity be kept to the minimum.

The replacing of essential instruments is becoming a luxury, and one is even forced into making uncomfortable economies on such items as hypodermic needles. New medical methods and improvements such as are advertised in the Journal are looked at with envy, and the annual holiday so necessary to prevent mental staleness is nothing but an increased financial burden if a locum has to be found at 14 guineas a week plus.

These, then, are some, but certainly not all, of the items that are contributing insidiously to the deterioration of general practice, and no amount of platitudes by the 